\title{
PERILAKU PEMENUHAN DAN PENYEBARAN INFORMASI PUBLIK BAGI MASYARAKAT KOTA DAN DESA
}

\author{
Vience Mutiara Rumata \\ Pusat Penelitian dan Pengembangan Aplikasi Informatika - Informasi dan Komunikasi Publik \\ Jalan Medan Merdeka Barat No. 9 Jakarta Pusat - 10110 \\ Telp./Fax: (021)3800418 \\ E-mail: vien001@kominfo.go.id
}

Naskah diterima tanggal 27 Februari 2017, direvisi tanggal 29 Maret 2017, disetujui tanggal 4 April 2017

\section{THE PUBLIC INFORMATION COMPLIANCE AND DISSEMINATION AMONG URBAN AND RURAL SOCIETY}

\begin{abstract}
In the information era, the abundance of information and access due to the internet has brought unprecedented challenges to the Ministry of Communication and Information Technology as public communication administrator. The internet penetration in Indonesia continues to grow annually. Nevertheless, does it reflect that the internet is the main source of public information? This research explores the public information compliance and dissemination among urban and rural societies. The research method is quantitative with the primary data is a survey at 12 provinces in Indonesia which were selected through probability sampling technique. It is a national survey with $2 \%$ margin of error estimation. The sample size reaches 2,500 respondents. The data analysis method is statistic-descriptive as the results as follows: the perception of public information particularly the government policies access is sufficiently well, although the popularity of the MCIT, as well as its local office's official media, is lower than television. The interpersonal relations and social environment influence someone to get and disseminate the information. The face to face communication is a prominent channel to disseminate information both in the urban and rural areas.
\end{abstract}

Keywords: explorative, public information, compliance, dissemination.

\begin{abstract}
Abstrak. Di era informasi seperti sekarang ini, ketersediaan informasi dan akses yang semakin mudah akibat internet telah membawa tantangan bagi Kementerian Komunikasi dan Informatika sebagai pengelola komunikasi publik. Tingkat penetrasi internet di Indonesia terus tumbuh tiap tahunnya. Namun, apakah ini mencerminkan bahwa internet menjadi sumber informasi publik? Penelitian ini mengeksplorasi perilaku pemenuhan kebutuhan informasi serta diseminasi informasi masyarakat kota dan desa. Metode penelitian ini adalah kuantitatif dengan pengumpulan data primer melalui penyebaran kuesioner di 12 provinsi di Indonesia yang telah dipilih dengan teknik probability sampling secara bertahap dan perkiraan margin of error sebesar 2\% dengan jumlah sampel mencapai 2.500 orang melalui kish grid. Metode analisis data adalah statistik deskriptif dengan hasil yaitu: persepsi responden mengenai akses terhadap informasi kebijakan pemerintah cukup baik meski popularitas media resmi Kementerian maupun Dinas Kominfo lebih rendah dibandingkan televisi. Faktor kedekatan interpersonal dan lingkungan sosial juga memengaruhi seseorang mendapatkan dan menyebarkan informasi. Komunikasi tatap muka merupakan saluran utama dalam penyebaran informasi baik di kota maupun desa.
\end{abstract}

Kata kunci: eksplorasi, informasi publik, pemenuhan, diseminasi. 


\section{PENDAHULUAN}

Di era informasi seperti saat ini, internet menjadi medium yang diakses warga untuk memenuhi kebutuhan informasi sehari-hari. Perkembangan teknologi web 2.0 pada internet telah memberikan dampak signifikan bagi individu, yaitu desentralisasi produksi hingga diseminasi informasi. Artinya bahwa setiap individu dapat memproduksi hingga menyebarkan informasi melalui internet. Ketersediaan informasi semakin berlimpah meski pemerataan akses belum tercapai sepenuhnya. Hal ini menjadi tantangan yang berat bagi pemerintah dalam menyediakan informasi publik di tengah jutaan informasi yang tersebar di internet.

Penetrasi internet di Indonesia terus meningkat dari tahun ke tahun. Data terbaru yang dikeluarkan Asosiasi Penyelenggara Jasa Internet Indonesia (APJII) tahun 2016 menunjukkan pengguna internet di Indonesia di tahun tersebut mencapai 132,7 juta orang atau sebesar $51,7 \%$ terhadap populasi penduduk (APJII, 2016). Dengan data yang sama, media yang paling sering digunakan untuk mengakses internet adalah menggunakan telepon selular sebesar 92,8 juta pengguna $(69,9 \%)$. Jumlah tersebut naik dari tahun 2014 sebelumnya yang mencapai 88,1 juta pengguna.

Meski penetrasi internet terus meningkat tiap tahunnya, teknologi komunikasi ini masih belum menjadi pilihan utama bagi masyarakat Indonesia dalam mendapatkan informasi publik. Hal ini terlihat dari popularitas website di Indonesia masih diduduki oleh web berbasis global seperti Google.com dan Youtube.com. Sementara, Detik.com menduduki urutan keempat website populer di Indonesia (Alexa, 2017). Survei Indikator TIK tahun 2015 yang dipublikasikan oleh Badan Litbang SDM Kementerian Komunikasi dan Informatika menemukan bahwa aktivitas "mencari informasi organisasi pemerintahan" menduduki peringkat ke-10 (dari 16 aktivitas) atau sebesar $28,4 \%$ sementara "membuka situs jejaring sosial" menduduki peringkat pertama $(72,3 \%)$ sebagai aktivitas yang sering dilakukan oleh pengguna internet (Tim Indikator TIK Pusat Litbang PPI, 2015).

Sebagai regulator di bidang komunikasi dan informatika, Kementerian Komunikasi dan Informatika (Kemkominfo) memiliki tugas pokok yang salah satunya adalah penyedia dan diseminasi informasi publik. Beberapa regulasi telah diberlakukan untuk menjamin pemenuhan hak publik akan informasi publik, salah satunya adalah Undang-Undang (UU) No. 14 tahun 2008 tentang Keterbukaan Informasi Publik. Di dalam UU ini mewajibkan Badan Publik untuk "menyebarluaskan Informasi Publik..., disampaikan dengan cara yang mudah dijangkau oleh masyarakat dan dalam bahasa yang mudah dipahami" (Pasal 9 (4)). Melalui Instruksi Presiden (Inpres) No. 9 tahun 2015 tentang Pengelolaan Komunikasi Publik, Kemkominfo mendapatkan tugas salah satunya adalah menyusun dan menyebarluaskan narasi tunggal dan data pendukung terkait kebijakan dan program pemerintah kepada publik. Bahkan dengan tegas dalam Inpres tersebut, informasi harus disampaikan "melalui berbagai saluran komunikasi kepada masyarakat secara tepat, cepat, objektif, berkualitas baik, berwawasan nasional, dan mudah dimengerti ..." (butir PERTAMA Inpres No. 9 tahun 2015).

Internet adalah medium yang efektif bagi Kemkominfo untuk menjalankan amanat tersebut. Kemkominfo pun telah mengintegrasikan internet sebagai salah satu alat penyebaran informasi publik, salah satunya adalah www.indonesiabaik.id. Namun, penelitian ini bukan meneliti seberapa efektifnya media online resmi Kemkominfo dalam mendiseminasikan informasi publik. Melainkan, mengkaji perilaku pemenuhan kebutuhan informasi serta diseminasi informasi masyarakat. Data ini menjadi penting bagi badan publik 
seperti Kemkominfo dalam menyusun strategi pengelolaan informasi publik. Data survei nasional terkait perilaku pemenuhan kebutuhan serta diseminasi informasi masih terbatas. Karena itu, penelitian ini mengeksplorasi perilaku pemenuhan serta diseminasi informasi publik atau dalam hal ini secara spesifik kebijakan atau program pemerintah, baik itu masyarakat kota maupun desa.

Penelitian ini menitikberatkan pada "Bagaimana perilaku pemenuhan dan penyebaran informasi publik masyarakat kota dan desa?". Untuk menjawab hal tersebut, maka penelitian ini meliputi perilaku pemenuhan kebutuhan informasi publik (media yang digunakan) hingga diseminasi informasi publik (kepada siapa dan media yang digunakan untuk menyebarkan informasi publik) serta persepsi terhadap badan publik penyedia informasi publik. Tujuan dari penelitian ini adalah mendapatkan gambaran perilaku dan penyebaran informasi publik masyarakat kota dan desa. Dengan demikian, data ini diharapkan dapat memberikan informasi kepada Direktorat Jenderal Informasi dan Komunikasi Publik (Ditjen IKP) Kementerian Kominfo selaku perumus dan penyusun kebijakan terkait strategi informasi dan komunikasi publik.

\section{LANDASAN KONSEP}

\section{Pemenuhan Kebutuhan Informasi}

Untuk mengetahui apa yang menjadi kebutuhan informasi, perlu mengetahui definisi 'informasi' terlebih dahulu. Informasi merupakan sekumpulan simbol yang memiliki makna, dapat dikomunikasikan, memiliki dampak, dan berguna untuk pengambilan keputusan (Fidel, 2012).

Definisi Informasi Publik, berdasarkan UU No. 14/ Tahun 2008 tentang Keterbukaan Informasi Publik, adalah "informasi yang dihasilkan, disimpan, dikelola, dikirim, dan/atau diterima oleh suatu badan publik yang berkaitan dengan penyelenggara dan penyelenggaraan negara ... serta informasi lain yang berkaitan dengan kepentingan publik" (Pasal 1(2)). Lebih lanjut, informasi publik bersifat terbuka dan dapat diakses (accessible) oleh siapa saja atau dalam UU disebut "pengguna informasi publik" (Pasal 2(1)). Adapun UU mengatur tiga jenis informasi publik yang wajib disediakan oleh badan publik: 1) Informasi yang wajib disediakan dan diumumkan secara berkala (Pasal 9); 2) Informasi yang wajib diumumkan secara serta merta (pasal 10); 3) Informasi yang wajib tersedia setiap saat.

Di dalam penelitian ini, informasi publik yang dimaksud adalah kebijakan pemerintah yang disampaikan oleh pejabat publik dalam pertemuan yang terbuka secara umum dan disebarkan melalui media massa dan media internet.

Tom D. Wilson adalah ilmuwan ternama untuk kajian ilmu informasi (information science) khususnya perilaku pencarian informasi (information-seeking behavior). Awalnya kajian perilaku pencarian informasi ditujukan bagi pengguna perpustakaan. Kajian ilmiah ini semakin berkembang setelah adanya konferensi Royal Society Scientific Information yang diselenggarakan pertama kali pada 1948 (Wilson, 2000).

Wilson (1984) berpendapat bahwa ilmu informasi bukanlah kajian disiplin yang dibangun dari satu kesatuan hukum atau prinsip teoretis yang bersifat monopoli. Melainkan, sebuah ilmu praktis (sama halnya dengan ilmu kedokteran maupun ilmu pertanian) di mana beragam disiplin ilmu dapat memberikan kontribusi terhadap metode dan temuan-temuan penelitian ilmu informasi tersebut. Karenanya, beberapa kajian sub disiplin ilmu informasi yang bermunculan seperti: studi perilaku konsumen, studi komunikasi bidang kesehatan, studi pengambilan keputusan organisasi, hingga studi desain sistem informasi.

Model perilaku pencarian informasi yang diusulkan oleh Wilson (1981) terdiri 
dari tiga elemen: 1) kebutuhan informasi; 2) faktor penghambat pencarian informasi; dan 3) perilaku pencarian informasi itu sendiri. Akar permasalahan kajian perilaku pencarian informasi adalah konsep kebutuhan informasi (Wilson, 1997). Kalangan akademisi, khususnya di era 1940an hingga akhir 1970an, gagal mendefinisikan 'kebutuhan informasi' utamanya karena sulit memisahkan definisi tersebut dengan konsep 'keinginan', 'permintaan yang diekspresikan', 'permintaan yang dipuaskan' dan sebagainya (Wilson, 1981). Menurut Wilson, 'kebutuhan' terkait pengalaman subjektif, realitas (image) dan frame of reference yang dipersepsi oleh individu secara kognitif, yang sulit diakses oleh peneliti atau observer. Faktor-faktor pengaruh yang memicu kebutuhan informasi dan perilaku pencarian informasi menurut Wilson (1977), diantaranya: faktor pengaruh sosial; faktor pengaruh kemampuan mengetahui informasi yang dibutuhkan; hingga faktor kemampuan menganalisa kebutuhan informasi untuk menyelesaikan pekerjaan atau faktor pengaruh lingkungan.

Ketika seseorang merasa butuh informasi, maka ada dorongan - motivasi sehingga terlibat dalam perilaku mencari informasi. Secara teoretis, 'motivasi' mengandung apa yang disebut dengan $a$ believe-value matrix (Burnkrant, 1976 dalam Wilson, 1997:553), yang berisi citra dari objek-objek (images of objects) yang muncul akibat pengalaman masa lampau dan relevan dengan kebutuhan (informasi) yang muncul serta diyakini memiliki nilai yang dapat memenuhi kebutuhan (informasi) yang dimaksud.

Dimensi kedua kajian perilaku pencarian informasi dan pemenuhan kebutuhan informasi adalah penghambat pencarian informasi (barriers) di mana ada tiga faktor dominan yaitu: faktor personal, faktor sosial (interpersonal), dan faktor lingkungan (Wilson, 1997). Faktor personal terdiri dari variabel emosi (psikologi), pendidikan dan demografi. Faktor sosial atau interpersonal dapat memengaruhi seseorang untuk mendapatkan informasi apabila informasi tersebut dihasilkan dari interaksi interpersonal. Sementara, faktor lingkungan sebagai penghambat perilaku pencarian informasi bisa terjadi akibat letak geografi, budaya (termasuk kendala berbahasa).

Dimensi ketiga adalah perilaku pencarian informasi itu sendiri. Perilaku akan ada ketika individu sudah mengetahui potensi dan hambatan yang akan dihadapinya ketika mencari informasi yang dibutuhkan.

Jadi, untuk mempelajari perilaku pencarian informasi harus melibatkan pandangan yang holistik. Artinya, perilaku pencarian informasi tidak semata didorong oleh adanya kebutuhan informasi (kebutuhan kognitif atau kebutuhan afektif), tetapi juga pengaruh sosial dan lingkungan turut membentuk perilaku tersebut.

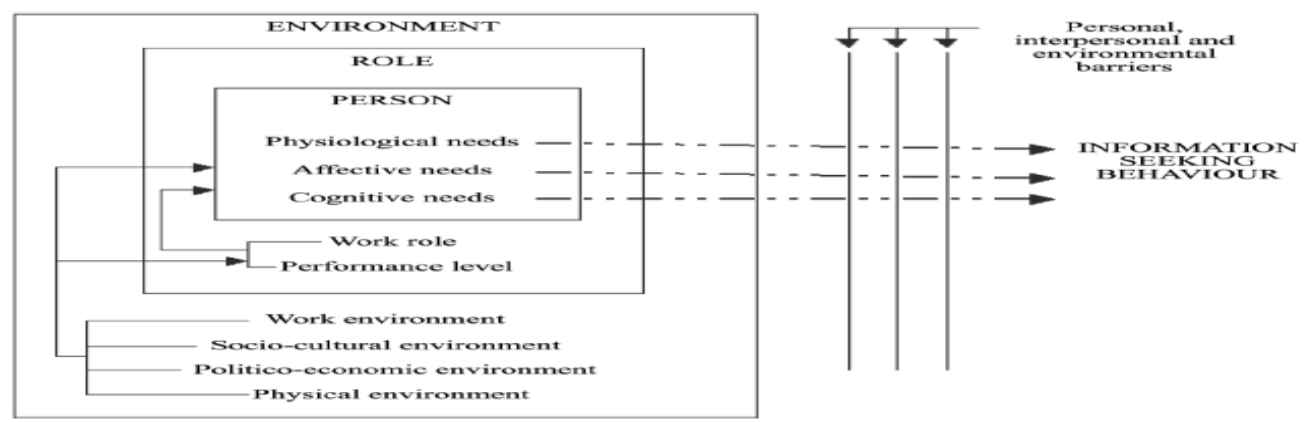

Sumber: Wilson dan Wanghsh (1981)

Gambar 1. Model Kebutuhan dan Pencarian Informasi 


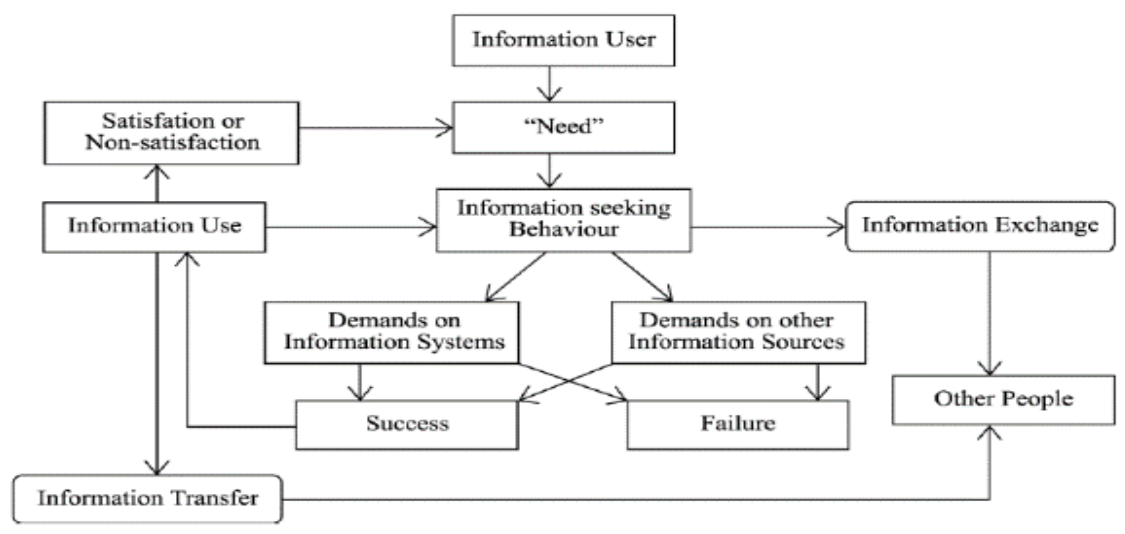

Sumber : Wilson dan Wanghsh (1981)

Gambar 2. Model Perilaku Informasi

Studi menemukan bahwa perilaku pencarian informasi dipengaruhi oleh akses terhadap informan baik itu secara formal maupun tidak formal atau baik personal ataupun melalui mediasi. Dalam studinya terhadap petani di pedesaan Uganda. Katungi, Edmeades, dan Smale (2008) menemukan bahwa minimnya akses terhadap sumber informasi formal terutama dari pemerintah (tenaga penyuluh), mengharuskan petani mendapatkan informasi dari sumber-sumber informasi non formal yang dalam hal ini sangat dipengaruhi oleh hubungan sosial (teman menjadi sumber informasi lebih baik dibandingkan dengan tetangga). Karenanya, kapital sosial merupakan determinan utama dalam pertukaran informasi secara informal bagi masyarakat pedesaan di Uganda.

Studi yang dilakukan oleh Bernal dan Vásquez (2016) menemukan bahwa masyarakat Guatemala masih bergantung pada media seperti televisi dan radio untuk mendapatkan informasi utamanya isu-isu dalam skala nasional. Sementara, isu-isu dalam skala lokal, mereka mendapatkan informasi dari lingkaran sosial mereka seperti tetangga, teman, dan sanak saudara. Jenis kelamin, status ekonomi, pendidikan turut memengaruhi perilaku pencarian informasi. Penelitian tentang kebutuhan informasi publik pernah dilakukan oleh Badan Litbang SDM Kemkominfo pada tahun 2015, yaitu survei yang ditujukan bagi responden masyarakat yang tinggal di wilayah perbatasan, tertinggal dan daerah maritim (nelayan). Pada penelitian tersebut, pendekatan kebutuhan informasi diarahkan pada konteks kebutuhan dasar manusia seperti: informasi sandang, pangan, papan, kesehatan, pendidikan, sanitasi dan sebagainya (Pusat Litbang APTIKA-IKP, 2015).

Tiga hal yang menjadi fokus penelitian ini yaitu: 1) Pola kebutuhan informasi; 2) Perilaku pencarian informasi; serta, 3) Penggunaan media bagi ketiga kelompok masyarakat tersebut. Beberapa poin penting hasil penelitian di antaranya: Informasi tentang pangan merupakan informasi yang paling dibutuhkan oleh ketiga kelompok masyarakat tersebut. Informasi tentang pangan di antaranya: harga sembako, ketersediaan bahan pokok, pasar tempat memperoleh sembako hingga kebijakan pemerintah terkait pangan (Pusat Litbang APTIKA-IKP, 2015).

Sementara lokasi pencarian informasi paling sering dilakukan di rumah dengan menggunakan media televisi. Sumber informasi yang digunakan untuk informasi pangan adalah televisi $34 \%$ - $42 \%$, untuk masyarakat perbatasan; $27 \%$ - $35 \%$ untuk masyarakat tertinggal; serta $54 \%-63 \%$ untuk masyarakat nelayan atau maritim). Meski demikian, penelitian ini hanya memfokuskan pada informasi yang sifatnya lebih umum serta tanpa mengeksplorasi bagaimana perilaku diseminasi informasi tersebut. Kesenjangan ini yang hendak dipenuhi dalam penelitian ini. 


\section{Penyebaran Informasi (Information Sharing)}

Diseminasi ataupun penyebaran informasi (information sharing) merupakan bagian dari interaksi sosial. Information sharing merupakan topik kajian multi disiplin ilmu. Karenanya, pengertian information sharing memiliki keberagaman secara konstruktual. Dalam studi manajemen Human Information Interaction (HII), information sharing menjadi fokus dalam mempelajari alur informasi baik antar manusia, maupun manusia dengan mesin (komputer). Laboratory Information System (LIS) menggunakan kata 'giving' untuk menggambarkan sharing information, yaitu sebagai sebuah tindakan untuk mendiseminasikan pesan-pesan dalam rangka membantu orang lain secara informal (Fidel, 2012). Dalam ilmu komunikasi, information sharing merupakan bagian dari interaksionisme secara simbolik (Symbolic Interaction Theory) dengan asumsi bahwa setiap individu akan membangun makna (meaning) melalui proses komunikasi dengan tujuan untuk berbagi makna (shared meaning) (West \& Turner, 2010).

Keberhasilan penyebaran informasi juga ditentukan oleh media yang digunakan sebagai salurannya, baik itu yang sifatnya langsung seperti komunikasi tatap muka, atau komunikasi yang termediasi teknologi. Untuk menguji alur informasi pada komunikasi kelompok, Graetz et al. (1998) melakukan eksperimen melalui tiga jenis komunikasi: tatap muka, telekonferensi, dan chatting. Komunikasi kelompok melalui chatting sulit dalam mengambil keputusan bersama, dibandingkan komunikasi tatap muka dan komunikasi melalui telekonferensi. Performa penyebaran informasi akan menyusut dalam komunikasi yang dimediasi oleh aplikasi chat karena individu cenderung menyimpan ide atau gagasannya ketika berpartisipasi dalam media ini. Menariknya, komunikasi kelompok melalui telekonferensi relatif lebih baik dibandingkan dengan komunikasi kelompok melalui tatap muka. Diskusi kelompok melalui telekonferensi sifatnya lebih homogen, terbuka dan akurat, dan biasanya disukai oleh kelompok pakar atau ahli.

Media massa seperti televisi dipandang lebih efektif dalam serempak dengan sasaran yang jauh lebih luas dibandingkan dengan internet, menimbang kesenjangan digital di wilayah Indonesia. Meski demikian, efektivitas media massa dalam menyampaikan informasi sesuai dengan target sasaran penerima pesan patut dipertanyakan.

Berdasarkan deskripsi konseptual kajian perilaku pencarian informasi dan pemenuhan kebutuhan informasi tersebut, penelitian ini mengeksplorasi perilaku pencarian hingga diseminasi informasi masyarakat kota dan desa. Tidak hanya itu, penelitian ini juga mengeksplorasi persepsi masyarakat terhadap lembaga yang membidangi bidang komunikasi dan informatika terkait sebagai sumber informasi publik.

\section{METODE PENELITIAN}

Penelitian ini merupakan bagian dari penelitian "Pola Komunikasi dan Perilaku Sosial Masyarakat Kota dan Desa di era TIK”, Pusat Penelitian dan Pengembangan Aplikasi Informatika dan Informasi dan Komunikasi Publik, Badan Litbang SDM, Kementerian Komunikasi dan Informatika tahun 2016. Metode penelitian ini adalah kuantitatif dengan pengumpulan data primer melalui survei atau penyebaran kuesioner. Lokus penyebaran kuesioner dilakukan di 12 provinsi yang telah dipilih dengan menggunakan teknik probability sampling secara bertahap. Tahap pertama yaitu penstrataan provinsi berdasarkan jumlah penduduk, tingkat akses rumah tangga terhadap internet dan kepemilikan HP oleh individu (Pusat Litbang APTIKA IKP, 2016). Seluruh 12 provinsi tersebut 
mewakili strata tinggi (lima provinsi), strata sedang (empat provinsi); dan strata rendah (tiga provinsi) yaitu: DKI Jakarta, Jawa Barat, Jawa Timur, Kalimantan Timur, Sumatera Selatan, Bali, Kalimantan Selatan, Sulawesi Utara, Sulawesi Selatan, Sumatera Utara, Sulawesi Tenggara, dan Papua Barat.

Sementara sampling tingkat individu dilakukan dengan mempertimbangkan sampling error. Untuk survei tingkat nasional, jumlah perkiraan margin of error adalah 2\%, maka jumlah keseluruhan sampel individu sebanyak 2.500 orang. Meski demikian, jumlah kuesioner yang disebar adalah sebanyak 2.560 dengan pertimbangan adanya kemungkinan data yang tidak terisi seluruhnya.

Metode analisis data dilakukan dengan cara statistika deskriptif, yaitu metode yang berkaitan dengan pengumpulan, penyajian, dan peringkasan suatu gugus data sehingga memberikan informasi yang berguna dan digunakan untuk menjelaskan kuantitas pilihan jawaban responden atas pernyataan yang diajukan dalam kuesioner baik dalam bentuk tabel dan gambar. Informasi yang ditampilkan adalah: perilaku pencarian

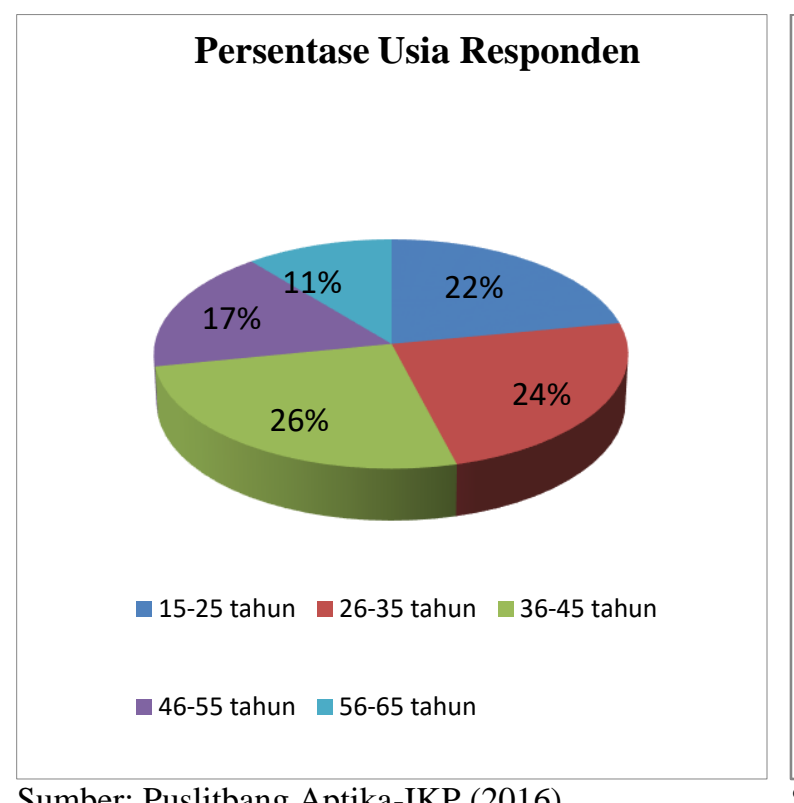

Sumber: Puslitbang Aptika-IKP (2016) Gambar 3. Proporsi Usia Responden informasi hingga diseminasi informasi, serta persepsi terhadap lembaga yang membidangi bidang komunikasi dan informatika terkait sebagai sumber informasi publik.

\section{HASIL PENELITIAN DAN PEMBAHASAN}

\section{Sosiodemografi Responden}

Sebanyak 2.552 kuesioner diolah dalam penelitian ini. Komposisi jenis kelamin responden penelitian cukup berimbang antara pria dan wanita, yakni $48,7 \%$ dan 51,3\%.Sementara, komposisi lokasi tempat tinggal didominasi oleh penduduk yang tinggal di desa sebesar $60 \%$.

Komposisi rentang usia responden penelitian ini didominasi oleh kelompok rentang usia 26-35 tahun (Gambar 3), dengan proporsi latar belakang pendidikan didominasi oleh pendidikan SMA/ sederajat (Gambar 4), serta proporsi latar belakang pekerjaan didominasi oleh Ibu Rumah Tangga (Gambar 5).

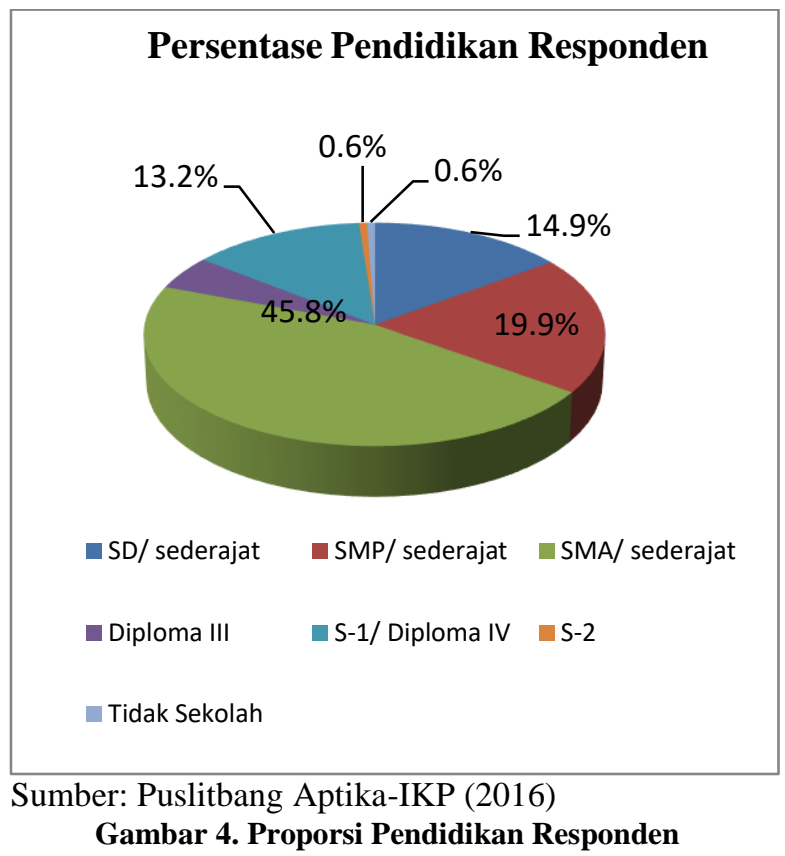




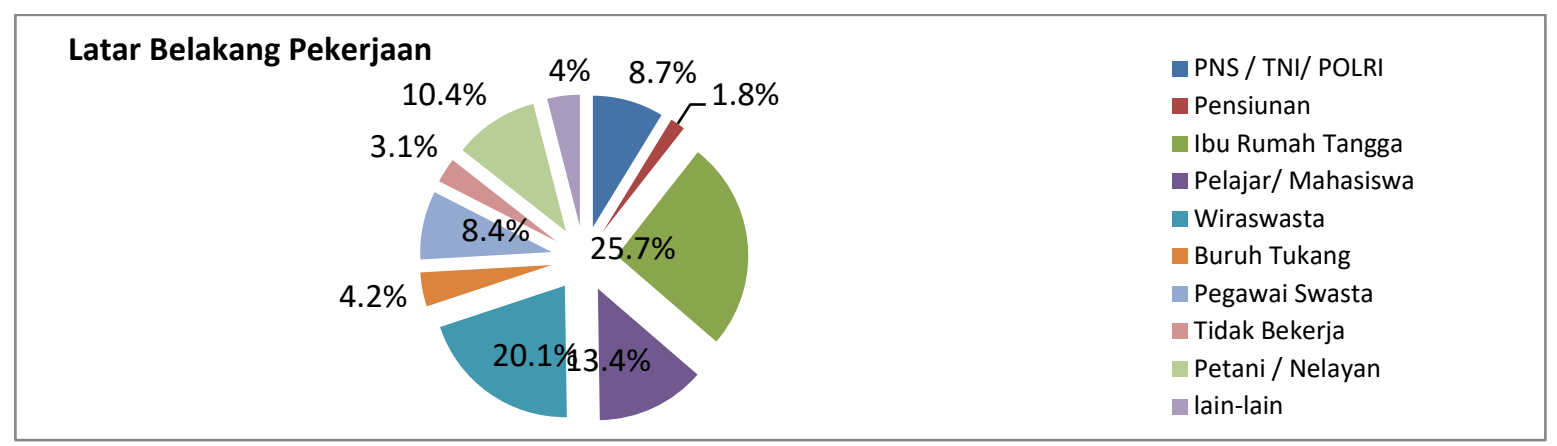

Sumber: Puslitbang Aptika-IKP (2016)

Gambar 5. Proporsi Pendidikan Responden

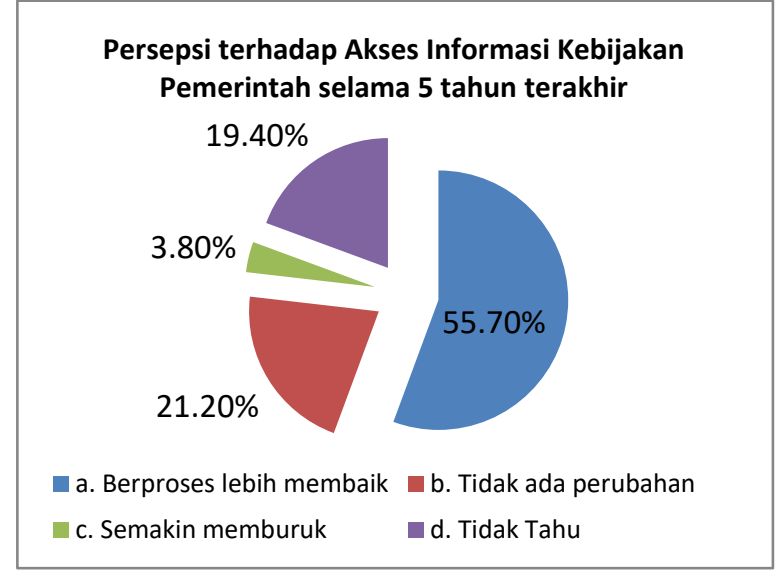

Sumber: Hasil Penelitian, Data Diolah Peneliti Gambar 6. Persepsi Responden terhadap Akses Informasi Kebijakan Pemerintah

\section{Pemenuhan Kebutuhan Informasi kebijakan Pemerintah}

Secara umum, persepsi responden terhadap akses informasi kebijakan pemerintah selama lima tahun terakhir berproses lebih baik (55,7\%). Artinya bahwa responden tidak mengalami kesulitan ketika mengakses informasi tentang pemerintah selama periode tersebut (Gambar 6). Hal ini dapat disebabkan oleh pertumbuhan penetrasi internet yang terus meningkat dari tahun ke tahun. Konten siaran pun mulai beragam dengan tumbuhnya televisi-televisi siaran nasional maupun siaran lokal. Televisi lokal memiliki program siaran berita yang cukup besar, khususnya berita lokal. Sebagai contoh, stasiun televisi solo TATV memiliki 14 jenis program berita (atau $37 \%$ dari total siaran), stasiun TV Surabaya JTV memiliki 15 jenis program berita lokal dan satu program berita mancanegara (atau 34\% dari

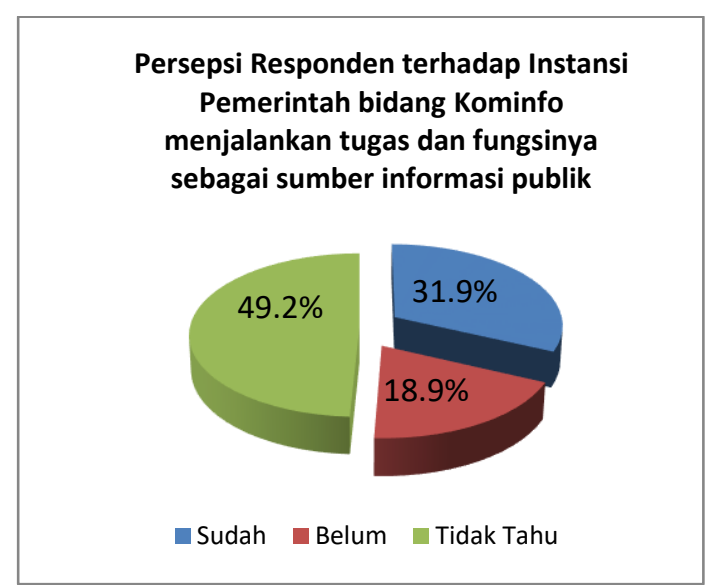

Sumber: Hasil Penelitian, Data Diolah Peneliti Gambar 7. Persepsi Responden terhadap Instansi Pemerintah bidang Kominfo sebagai Sumber Informasi Publik

total siaran); stasiun JogjaTV memiliki 12\% siaran berita (Sugihartono, 2009).

Meski persepsi responden cukup baik terhadap akses informasi publik, namun persepsi terhadap instansi yang membidangi komunikasi dan informatika (baik itu di pusat maupun di daerah) sebagai sumber informasi publik tidak begitu baik. Sebanyak 49,2\% responden menjawab tidak tahu bila instansi-instansi tersebut memiliki peran sebagai sumber informasi publik. Sementara, hanya 31,9\% responden memersepsikan bahwa instansiinstansi tersebut sudah menjalankan tugas dan fungsinya sebagai informasi publik. Sementara $18,9 \%$ menjawab belum (Gambar 7).

Persentase masyarakat kota yang memersepsikan bahwa instansi pemerintah bidang komunikasi dan informatika sudah menjalankan fungsinya sebagai sumber informasi publik lebih besar yaitu 38,58\% 
dibandingkan dengan masyarakat desa 27,42\%. Meski demikian, presentasi masyarakat kota yang tidak tahu kinerja instansi tersebut lebih besar dibandingkan mereka yang tahu, yaitu sebesar $42,18 \%$. Meski tidak terlalu signifikan, masyarakat desa lebih didominasi oleh mereka yang tidak tahu yaitu $53,85 \%$ dibandingkan dengan mereka yang tahu yaitu $46,16 \%$ (Grafik 1).

Data menunjukkan bahwa kesadaran maupun persepsi terhadap sumber penyedia informasi terutama instansi yang membidangi komunikasi dan informatika cukup rendah. Hal ini memengaruhi motivasi seseorang untuk mencari informasi yang berasal dari sumber-sumber tersebut. Konsep "motivasi" sangat digunakan untuk menganalisa perilaku pencarian informasi (Wilson, 1997). Ketika seseorang mengalami atau menyadari adanya kebutuhan informasi, hal ini yang memotivasi seseorang untuk berperilaku mencari informasi. Di dalam teori motivasi, secara umum, memiliki asumsi bahwa dalam diri individu manusia memiliki apa yang disebut belief-value matrix, yaitu kumpulan-kumpulan objek atau citra yang mencerminkan pengalaman-pengalaman masa lalu yang relevan untuk memuaskan kebutuhan. Matriks ini, menurut penulis, menentukan bagaimana individu memilih media sebagai bagian dari perilaku pencarian informasi.

Berdasarkan model kebutuhan dan pencarian informasi (Wilson, 1981) (Gambar 1 ), setidaknya ada tiga dimensi penghalang (barrier) seseorang untuk mencari informasi, yaitu: hambatan personal (personal barrier); hambatan sosial atau berhubungan dengan peran (social or role-related barriers); dan hambatan lingkungan (environment barrier). Hambatan personal melibatkan tiga variabel: kondisi emosi, variabel pendidikan (level pengetahuan), dan variabel demografi (Wilson, 1997). Di dalam kajian psikologi, individu manusia memiliki apa yang disebut cognitive dissonance, sebuah kondisi yang berseberangan antara perilaku dengan kognitif (pikiran) diri seseorang (misalnya orang sadar bahaya merokok, tetapi masih tetap merokok). Untuk mengatasi kondisi seperti ini, maka seseorang akan berupaya untuk mencari informasi untuk memperbaiki perilakunya ataupun memperkuat keyakinan atau persepsi yang sudah ada. Karena minimnya pengetahuan terhadap instansi pemerintah yang membidangi komunikasi dan informatika, maka seseorang akan merujuk media lain sebagai sumber informasi bagi dirinya. Hal ini terlihat dari temuan penelitian ini, bahwa pemenuhan kebutuhan informasi kebijakan pemerintah dipenuhi oleh utamanya televisi (84\%); kemudian tetangga sekitar rumah atau teman $(53,8 \%)$ dan internet $(27,2 \%)$. Sebaliknya, informan formal (tenaga penyuluh) menduduki peringkat terendah yaitu $7,9 \%$. Hal ini menempatkan bahwa tenaga penyuluh bukanlah sumber informan yang efektif dalam menyampaikan informasi kebijakan pemerintah (Grafik 2 ).

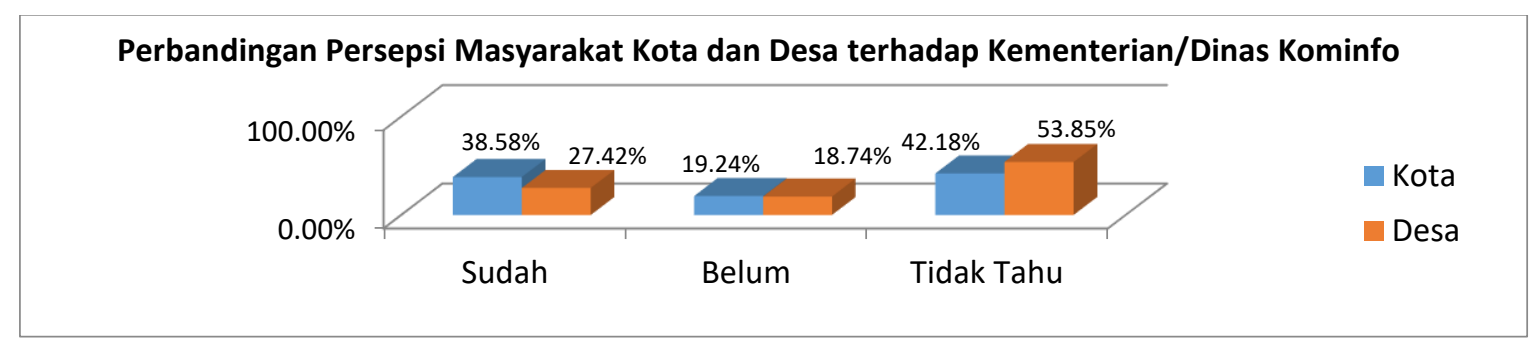

Sumber: Hasil Penelitian, Data Diolah Peneliti

Grafik 1. Persepsi Responden terhadap Instansi Pemerintah bidang Kominfo sebagai Sumber Informasi Publik berdasarkan Wilayah Tinggal 


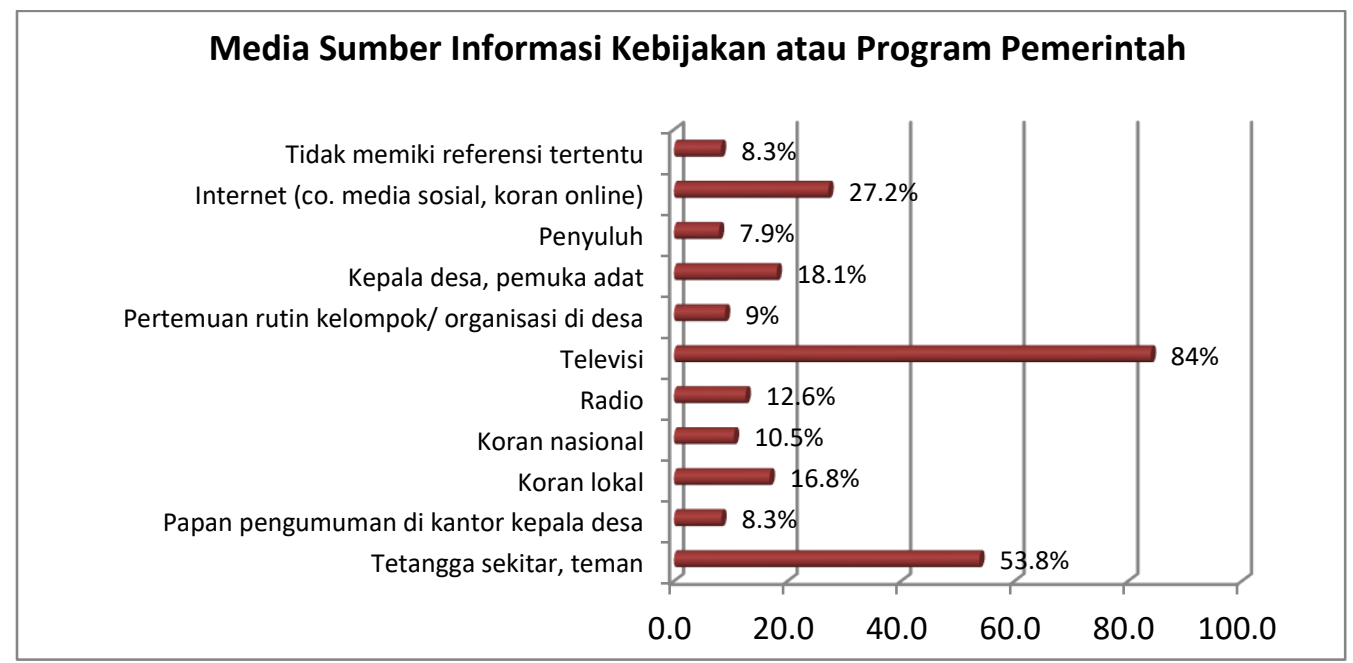

Sumber: Hasil Penelitian, Data Diolah Peneliti

Grafik 2. Media Sumber Informasi Kebijakan atau Program Pemerintah

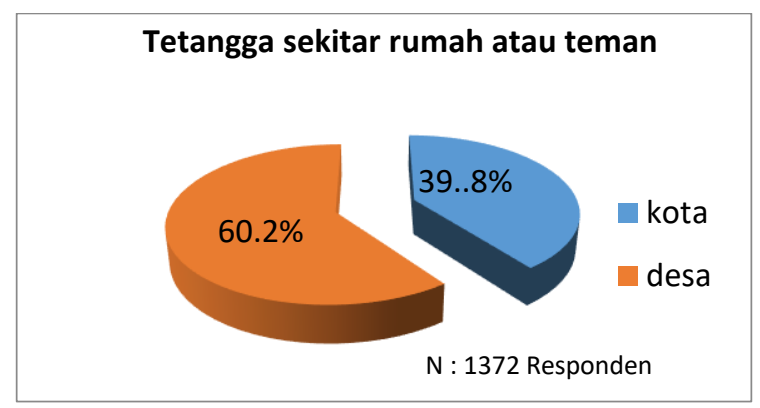

Sumber: Hasil Penelitian, Data Diolah Peneliti

Gambar 8. Persentase Masyarakat Kota dan Desa terhadap tetangga atau teman sebagai Sumber Informasi Kebijakan Pemerintah

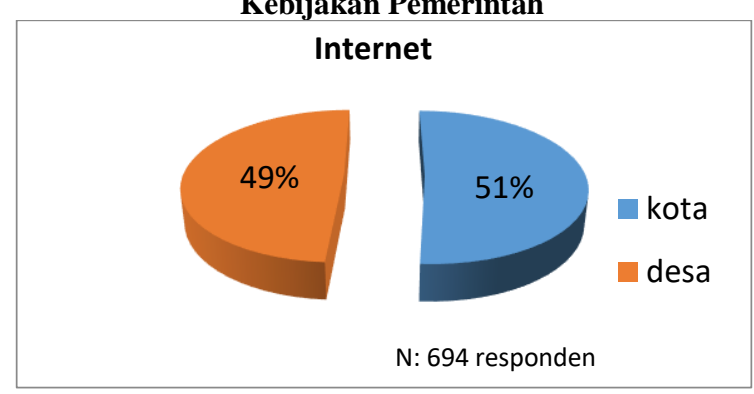

Sumber: Hasil Penelitian, Data Diolah Peneliti

Gambar 10. Persentase Masyarakat Kota dan Desa Menggunakan Internet Sebagai Sumber Informasi Kebijakan Pemerintah

Persentase antara masyarakat kota dan desa terhadap tiga media sumber informasi tersebut didapat bahwa televisi dan tetangga menjadi sumber informasi dominan bagi masyarakat desa, ketimbang masyarakat kota (Gambar 8 dan Gambar 9). Sementara media seperti internet tidak memiliki perbedaan yang timpang atau signifikan antara masyarakat kota dan desa, meski jumlah responden yang menjawab tidak sebanyak jumlah responden yang

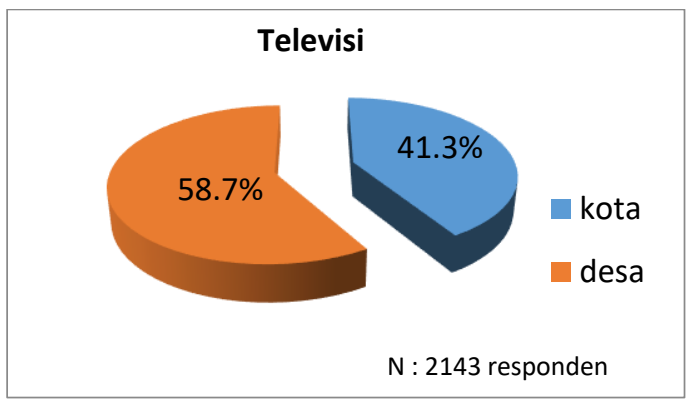

Sumber: Hasil Penelitian, Data Diolah Peneliti Gambar 9. Persentase Masyarakat Kota dan Desa Menggunakan Televisi sebagai Sumber Informasi Kebijakan Pemerintah

Penggunaan Media Resmi Kementerian atau

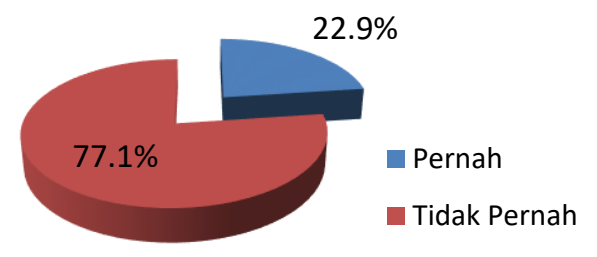

Sumber: Hasil Penelitian, Data Diolah Peneliti Gambar 11. Persentase Penggunaan Media Resmi Kementerian atau Dinas bidang Kominfo

menjawab televisi ataupun tetangga sekitar rumah atau teman (Gambar 10). Tiga media tersebut (televisi, tetangga sekitar rumah atau teman, serta internet) merupakan media utama yang digunakan responden untuk mendapatkan informasi publik yang dibutuhkan. Karenanya tidak mengherankan apabila data menunjukkan bahwa media resmi milik Kementerian ataupun Dinas yang membidangi Komunikasi dan Informatika belum 
populer di antara responden. Hal ini terlihat sebanyak $77,1 \%$ responden menyatakan tidak pernah mengakses media resmi yang dimaksud (Gambar 11). Dari sebanyak $22,9 \%$ yang mengakses media resmi tersebut, persentase masyarakat kota sebesar $52,91 \%$ (309 responden) dan masyarakat desa sebesar $47,09 \% \quad(275$ responden). Data ini juga memperkuat temuan sebelumnya yaitu ketidaktahuan responden tugas dan fungsi terhadap instansi-instansi tersebut sebagai sumber informasi publik (Gambar 7).
Dari 22,9\% responden yang menjawab pernah mengakses media resmi Kementerian atau Dinas Kominfo untuk mencari informasi publik, ditemukan bahwa media luar ruang merupakan media yang paling sering diakses yakni sebesar $9,2 \%$. Sementara media internet seperti media sosial resmi $(4,8 \%)$ dan website resmi $(4,1 \%)$ menduduki peringkat kedua dan ketiga. Portal seperti www.infopublik.org sedikit diakses oleh responden yakni sebesar $1,1 \%$ (Grafik 3).

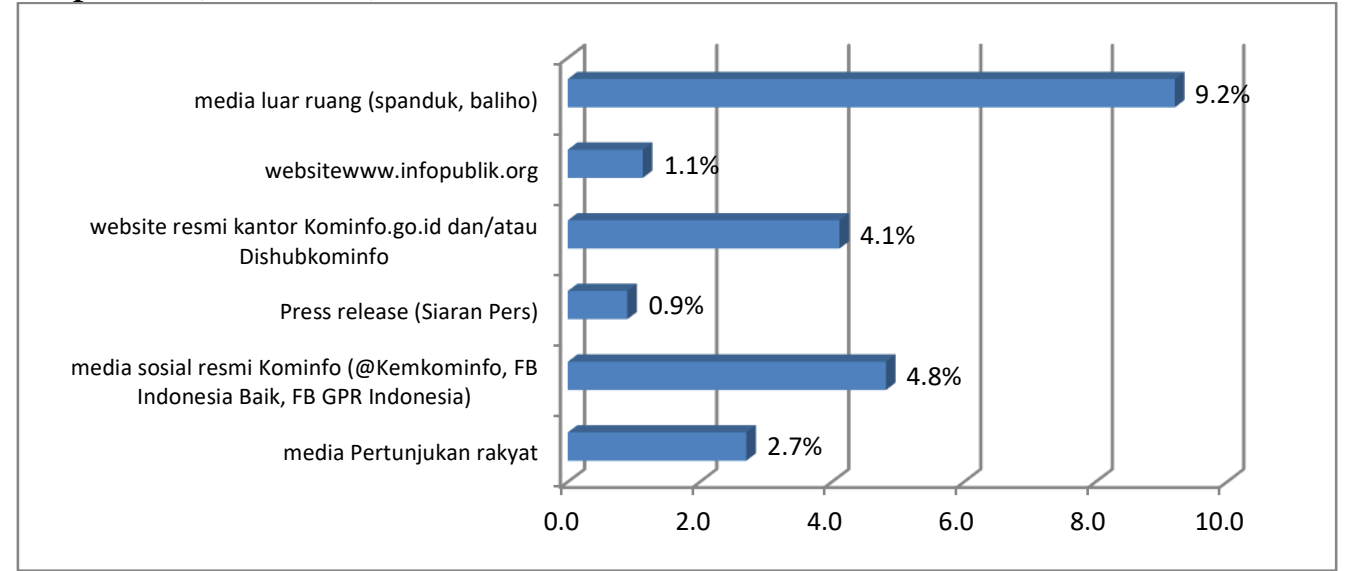

Sumber: Hasil Penelitian, Data Diolah Peneliti

Grafik 3. Media Resmi Kementerian atau Dinas Kominfo yang pernah Diakses Responden

PERILAKU PENGGUNA INTERNET INDONESIA

\section{(?) ALASAN UTAMA MENGAKSES INTERNET}
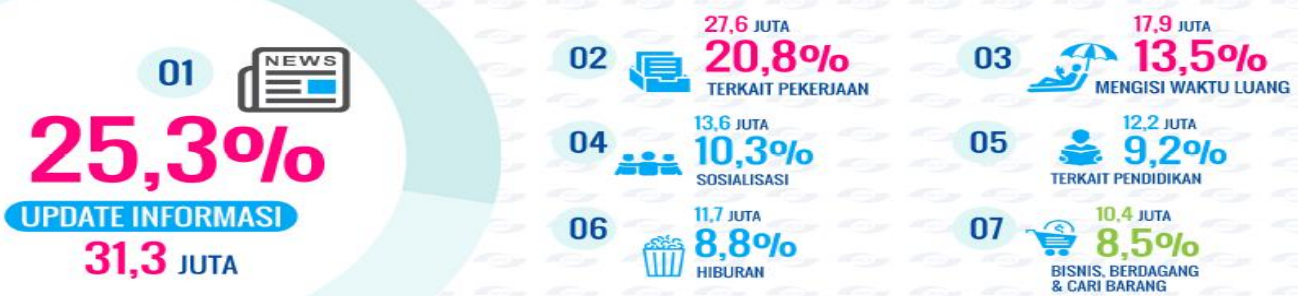

Sumber: APJII (2016)

Gambar 12. Alasan Utama Mengakses Internet

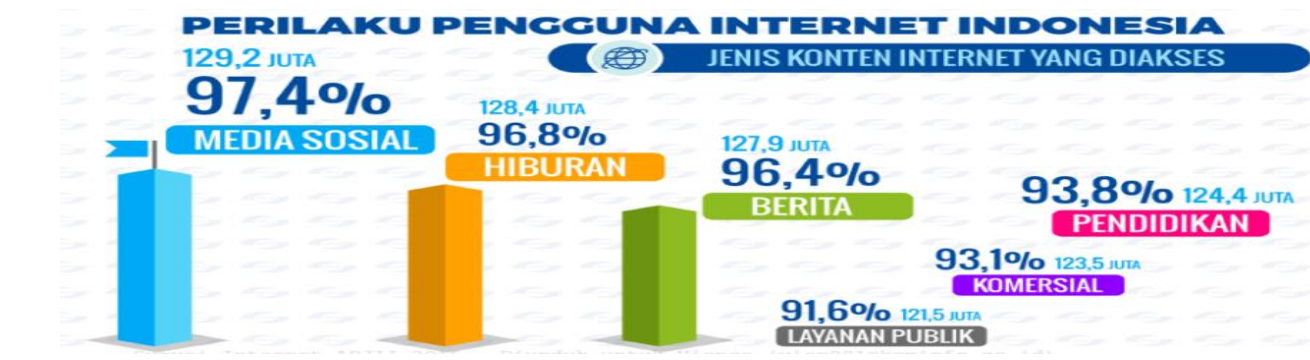

Sumber: APJII (2016)

Gambar 13. Jenis Konten Internet yang Diakses 
Dari data tersebut terlihat bahwa meski penetrasi penggunaan internet terus meningkat, tetapi penggunaan internet sebagai media mencari informasi publik belum terlalu tinggi dibandingkan dengan media lainnya. Jika disandingkan dengan temuan-temuan survei lainnya terkait perilaku akses internet, APJII (2016) menemukan tiga alasan utama mengakses internet yaitu update informasi terutama berita; terkait pekerjaan; dan mengisi waktu luang (Gambar 12). Akan tetapi, jenis konten yang paling sering diakses diantaranya: media sosial; hiburan; dan berita. Sementara, konten layanan publik menduduki posisi keenam yakni (Gambar 13). Data ini menunjukkan adanya perbedaan antara motivasi dengan perilaku ketika mengakses informasi melalui internet. Sama halnya dengan temuan penelitian ini, ketika internet menjadi media alternatif responden dalam mencari informasi, tetapi tidak serta merta meningkatkan perilaku pencarian informasi publik dengan mengakses media online resmi instansi-instansi yang membidangi komunikasi dan informasi publik.

Meski media resmi Kementerian dan atau Dinas Kominfo dapat dikatakan bukan sumber utama informasi kebijakan pemerintah, kesadaran responden terhadap kebijakan yang dikeluarkan, khususnya Kementerian Kominfo cukup baik. Hal ini terlihat dari beberapa responden yang mengetahui kebijakan khususnya Peraturan Menteri Kominfo No. 19 tahun 2014 tentang Penanganan Situs Internet Bermuatan Negatif $(9,6 \%)$, disusul dengan Undang-Undang (UU) No. 11/2008 tentang Informasi dan Transaksi Elektronik $(6,1 \%)$ dan UU No.14/2008 tentang Keterbukaan Informasi Publik (6\%) (Grafik 4).

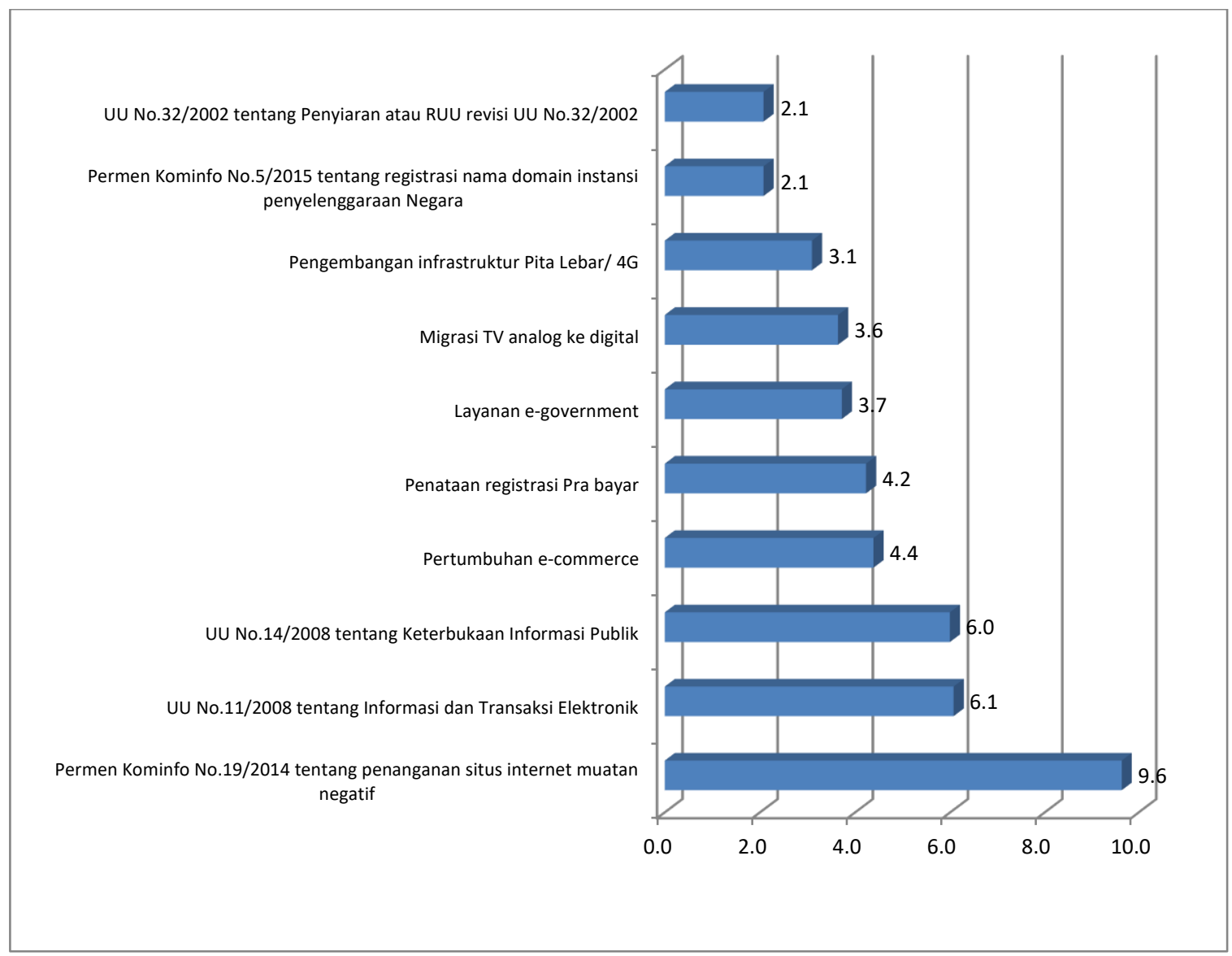

Sumber: Hasil Penelitian, Data Diolah Peneliti

Grafik 4. Popularitas Kebijakan dan/atau Program Kominfo 


\section{Orang yang sering disampaikan Informasi tentang Pemerintah}

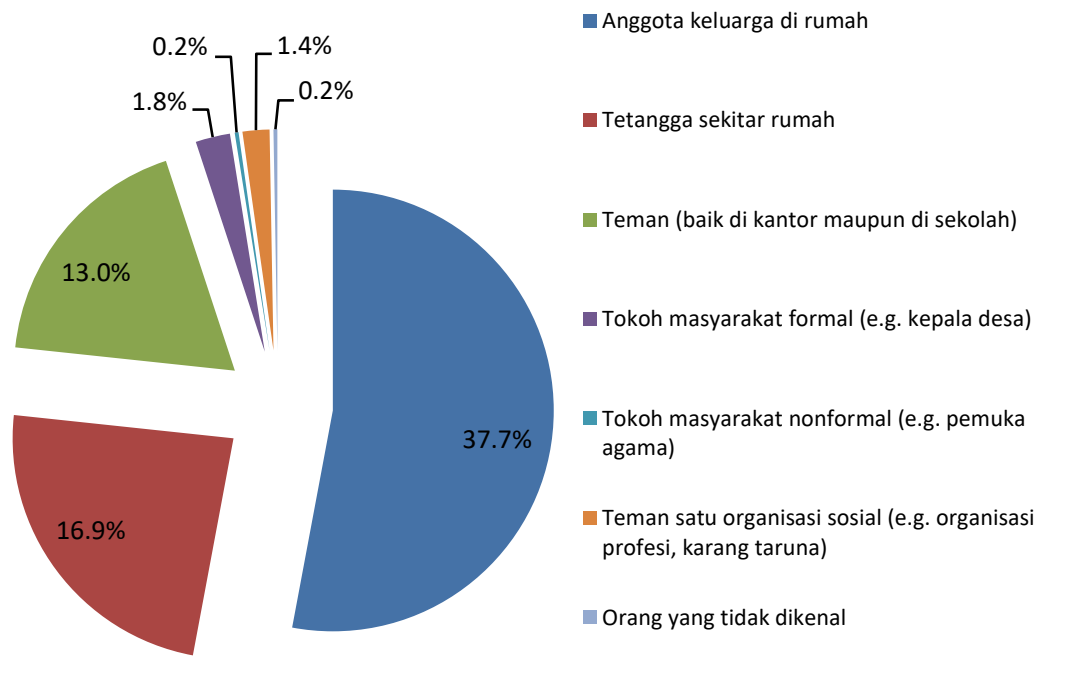

Sumber: Hasil Penelitian, Data Diolah Peneliti

Gambar 14. Komposisi Orang yang Sering Disampaikan Informasi tentang Pemerintah

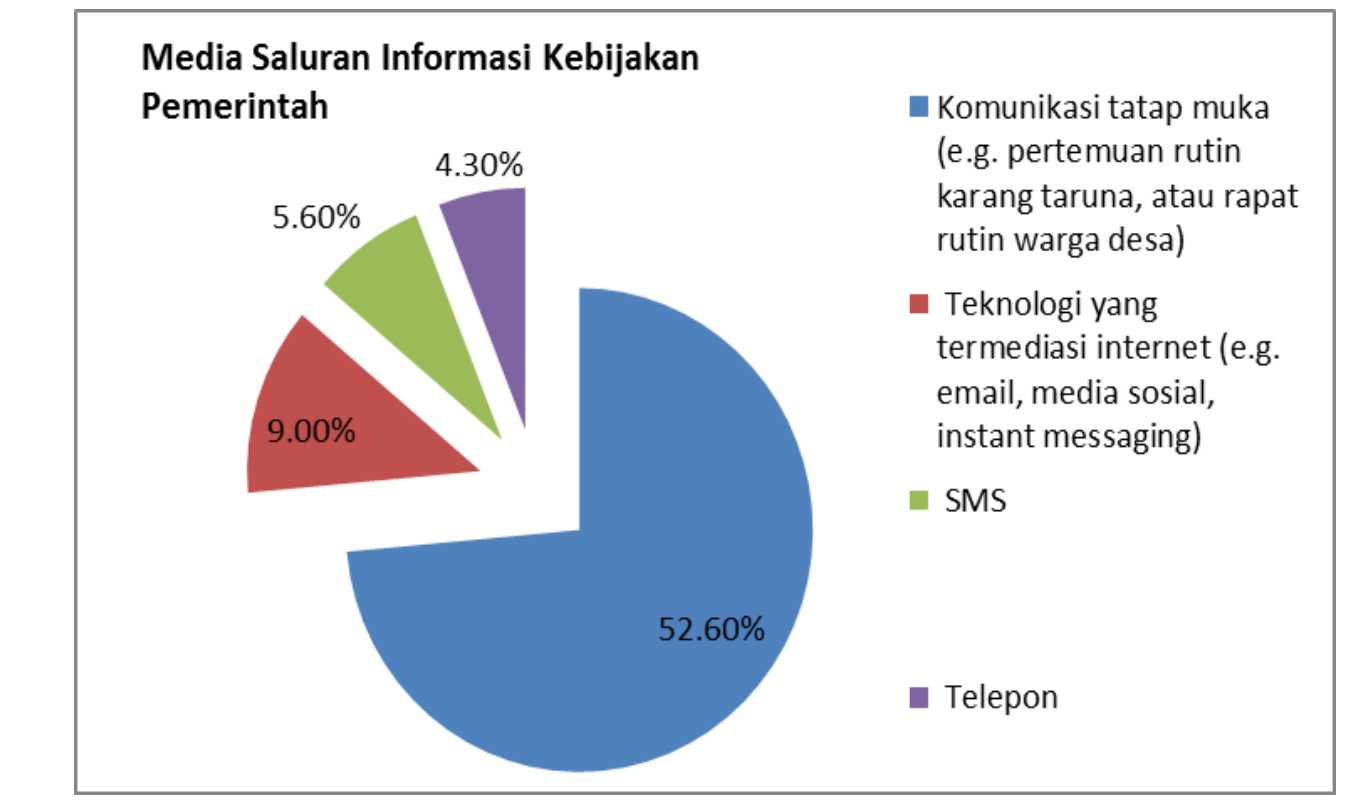

Sumber: Hasil Penelitian, Data Diolah Peneliti

Gambar 15. Media yang Digunakan untuk Diseminasi Informasi

\section{Penyebaran Informasi Publik}

Secara spesifik, pertanyaan kuesioner mempersempit istilah informasi publik dengan informasi tentang pemerintah (contohnya kebijakan pemerintah). Penelitian ini juga mengeksplorasi kecenderungan pola penyebaran informasi serta media yang digunakan untuk diseminasi informasi tersebut. Data temuan menunjukkan bahwa sebanyak $71,9 \%$ responden menyatakan pernah menyebarkan informasi terkait kebijakan pemerintah kepada orang lain. Responden memilih menyampaikan informasi tersebut kepada anggota keluarga $(37,7 \%)$, tetangga sekitar rumah $(16,9 \%)$ dan teman baik di kantor maupun di sekolah (13\%) (Gambar 14). 
Sementara, komunikasi tatap muka merupakan saluran utama diseminasi informasi pemerintah, yaitu sebesar 52,6\%. Media seperti internet juga digunakan responden untuk membagikan informasi kebijakan pemerintah, tetapi persentasenya cukup rendah yakni 9\% (Gambar 15). Faktor hubungan sosial dan interpersonal turut memengaruhi pola pemenuhan dan penyebaran informasi publik responden berdasarkan temuan survei ini. Tetangga sekitar rumah dan teman merupakan sumber informasi publik dominan kedua setelah televisi. Sementara, anggota keluarga merupakan penerima informasi publik dominan dan komunikasi tatap muka menjadi media utama penyebaran informasi publik. Hal ini dapat diperkuat dengan hasil penelitian yang dilakukan Pusat Litbang APTIKA-IKP tahun 2016 yang berjudul "Pola Komunikasi dan Perilaku Sosial Masyarakat Kota dan Desa di era TIK" bahwa tipe komunikasi masyarakat Indonesia didominasi oleh tipe komunikasi "konsensual" berdasarkan kerangka teori pola komunikasi keluarga Fitzpatrick dan Kroener (2002) (Pusat Litbang APTIKA IKP, 2016). Artinya bahwa orang Indonesia lebih suka berdiskusi secara tatap muka dan timbal balik, meski pada akhirnya keputusan ditentukan oleh aktor sosial yang memiliki kedudukan lebih tinggi dalam sistem maupun lingkungan sosial tersebut (konformitas tinggi).

\section{PENUTUP}

\section{Simpulan}

Tidak ada perbedaan yang signifikan antara masyarakat kota dan desa terkait pola pemenuhan hingga diseminasi informasi publik.

Secara umum, pola pemenuhan kebutuhan informasi dalam penelitian ini diawali dengan persepsi responden terhadap akses informasi publik serta tugas dan fungsi instansi pemerintah yang membidangi komunikasi dan informatika sebagai sumber informasi publik. Persepsi responden cenderung baik terkait akses mereka terhadap informasi publik dalam kurun waktu lima tahun belakangan. Meski demikian, persepsi publik terhadap instansi yang membidangi komunikasi dan informatika tersebut kurang baik. Hal ini memengaruhi motivasi serta perilaku pencarian informasi publik. Akibatnya, popularitas media resmi instansi-instansi tersebut kurang memadai bagi responden.

Temuan umum lainnya adalah tiga media utama yang digunakan responden untuk mendapatkan informasi publik, yaitu: televisi, tetangga sekitar rumah atau teman, serta internet. Televisi dan tetangga sekitar rumah menjadi sumber informasi dominan bagi masyarakat desa. Sementara, internet masih didominasi oleh masyarakat kota.

Tingginya penetrasi internet di Indonesia tidak serta merta mencerminkan tingginya akses terhadap media online layanan informasi publik. Hal ini terlihat dari sangat rendahnya akses terhadap media sosial resmi ataupun website resmi Dinas atau Kementerian yang membidangi komunikasi dan informatika, termasuk media portal informasi publik seperti www.infopublik.org milik Direktorat Jenderal Informasi dan Komunikasi Publik.

Penyebaran informasi publik lebih dominan dilakukan melalui komunikasi tatap muka terutama kepada anggota keluarga di rumah, tetangga sekitar rumah serta teman di sekolah maupun lingkungan tempat pekerjaan responden. Faktor sosial dan hubungan interpersonal menjadi faktor pembentuk motivasi responden dalam memenuhi kebutuhan dan penyebaran informasi.

\section{Saran}

Memperbesar anggaran komunikasi publik yang bertujuan untuk meningkatkan awareness (kesadaran publik)

Target audiens lebih difokuskan kepada masyarakat desa.

Saluran yang digunakan untuk diseminasi program awareness tersebut dapat dilakukan melalui televisi, media luar ruang, website serta media sosial resmi 
Kominfo. Penempatan akun media sosial resmi serta website resmi juga perlu didistribusikan secara masif dalam kegiatan diseminasi informasi publik tersebut.

Meski dalam penelitian ini didominasi oleh kelompok jenis kelamin perempuan yang berprofesi ibu rumah tangga, tetapi perlu dipertimbangkan menjadikan kelompok ini sebagai sasaran audiens utama untuk diseminasi informasi publik khususnya oleh Dinas Komunikasi Informatika baik tingkat Provinsi maupun Kabupaten/Kota. Karena mereka dapat menjadi sumber informasi bagi anggota keluarganya di rumah maupun tetangga di sekitar rumah.

\section{DAFTAR PUSTAKA}

Alexa (2017) Top Sites in Indonesia. [Online]. 2017. Available from: http://www.alexa.com/topsites/countries IID.

APJII (2016) Saatnya Jadi Pokok Perhatian Pemerintah dan Industri. Buletin APJII. [Online]. Available from: https://apjii.or.id/downfile/file/BULETI NAPJIIEDISI05November2016.pdf.

Bernal, A.T. \& Vásquez, W.F. (2016) Information sources and profile of informed citizens. Information Development. [Online] 32 (3), 709-717. Available from: doi:10.1177/0266666914568575.

Fidel, R. (2012) Human Information Interaction: An Ecological Approach to Information Behavior. The MIT Press.

Graetz, K.A., Boyle, E.S., Kimble, C.E., Thompson, P., et al. (1998) Information Sharing in Face-to-Face, Teleconferencing, and Electronic Chat Groups. Small Group Research. [Online] 29 (6), 714-743. Available from: doi:10.1177/1046496498296003.

Katungi, E., Edmeades, S. \& Smale, M. (2008) Gender, social capital and information exchange in rural Uganda. Journal of International Development. [Online] 20 (1), 35-52. Available from: doi:10.1002/jid.1426.
Pusat Litbang APTIKA - IKP (2016) Pola Komunikasi dan Perilaku Sosial Masyarakat Kota dan Desa di Era Teknologi Komunikasi. [Online]. 2016. Available from: https://balitbangsdm.kominfo.go.id/?mo $\mathrm{d}=$ publikasi\&a $=$ dl\&page_id $=223 \& \mathrm{cid}=$ 29\&download_id $=150$.

Pusat Litbang APTIKA-IKP (2015) Laporan Hasil Penelitian Survei Kebutuhan Informasi Masyarakat.

Sugihartono, R.A. (2009) Televisi Lokal Sebagai Medium Pencitraan Lokalitas Daerah. Acintya. [Online] 1 (1), 1-15. Available from: http://jurnal.isiska.ac.id/index.php/acintya/article/view/ 17.

Tim Indikator TIK Pusat Litbang PPI (2015) Hasil Survei Indikator TIK 2015 Rumah Tangga dan Individu. [Online]. Pusat Penelitian dan Pengembangan Penyelenggaraan Pos dan Informatika. Badan Litbang SDM Kementerian Komunikasi dan Informatika. Jakarta. Available from: https://balitbangsdm.kominfo.go.id/b erita-hasil-survei-indikator-tik-201519-114.

West, R. \& Turner, L. (2010) Introducing Communication Theory. New York, McGraw-Hill Higher Education.

Wilson, T.D. (2000) Human Information Behaviour. Informing Science. [Online] 3 (2), 49-55. Available from: http://inform.nu/Articles/Vol3/v3n2p4956.pdf.

Wilson, T.D. (1997) Information Behaviour: an Interdisciplinary Perspective*. Information Processing \& Management. 33 (4), 551-572.

Wilson, T.D. (1977) Investigation of Information Use and Users Needs As a Basis for Training-Programs. In: International Forum on Information and Documentation. 1977 International Forum on Information and Documentation. pp. 25-29.

Wilson, T.D. (1981) on User Studies and Information Needs. Journal of Documentation. [Online] 37 (1), 3-15. Available from: doi:10.1108/eb026702.

Wilson, T.D. (1984) The cognitive approach to information-seeking behaviour and information use. Social Science 
Information Studies. [Online] 4 (2-3),

197-204. Available from:

doi:10.1016/0143-6236(84)90076-0. 